\title{
Research on Integration of Students' Ability to Explore and Chemistry Teaching Method Innovation from the Ability Oriented Perspective
}

\author{
Ping Kong ${ }^{1}$ \\ ${ }^{1}$ Siping Vocational College, \\ Siping City, Jilin Province 136000 China
}

\begin{abstract}
In this paper, we conduct research on the integration of students' ability to explore and chemistry teaching method innovation from the ability oriented perspective. With the development of modern technology, the increasing of the general auxiliary teaching facilities, teaching methodology diversification will in the actual teaching process teaching is often mutual combination of several methods. College teachers should not only teach students new knowledge, to cultivate the student to obtain more knowledge. Our proposed approach could help enhance the student ability.
\end{abstract}

Keywords: Ability to Explore; Chemistry Teaching; Ability Oriented; Novel Perspective.

\section{Introduction}

Chemistry teaching method is the chemistry teachers in the teaching process in order to complete the teaching mission work mode and adopted by the students in the way of learning under the guidance of teachers, the teaching methods including teachers' teaching methods and students learning method from two aspects, this article mainly discuss the teacher's teaching method. With the development of modern technology, the increasing of the general auxiliary teaching facilities, teaching methodology diversification, in the actual teaching process teaching is often mutual combination of several methods. Because the teachers in the teaching process in a dominant position, in the teaching and research method, the law in a dominant position. Each teaching method has its own advantages and disadvantages, at the same, on the basis of the teaching content, teaching how to achieve the teacher professor and students' learning, the choice of teaching method is particularly important. Applied in analytical chemistry course in colleges and universities in the common problem could be summarized as the follows. (1) Teaching to improve teachers' teaching way. As a result of college expansion, the increase of the demand for teachers in colleges and universities, therefore, the school all courses are taught increased a lot of young teachers, the teachers' degree is high, the enthusiasm, but the teaching experience, understanding of the subject of analytical chemistry is not deep, so in the way of teaching. Plus the students have different the basis of analytical chemistry, ability to accept knowledge there are good and bad, also led to the learning effect is unsatisfactory. (2) Curriculum is not reasonable. Analytical chemistry this subject now there are many versions of the teaching material, content is extensive, course is high. But in the actual teaching process, not enough emphasis on chemistry course, result in less actual class, not showed the textbook knowledge in detail to the students, thus the teaching effect will surely be affected. (3) In recent years, the enrollment expansion of colleges and universities and chemical class talent employment demand, leading to chemical class growing number of students, teachers students to keep pace with huge increase obviously, analytical chemistry only large centralism teaching way in order to make sure most of the students can be involved in the classroom, but this teaching model is very 
difficult to take care of every student to the knowledge of different needs, in short to effective interaction between teachers and students in class. (4) Teaching content cannot be combined with practice. Analytical chemistry curriculum classes and a lot of content in the basic stage, coupled with the course content is widespread, strong theory and practice, it is always difficult to the analytical chemistry theory analysis was very deep, this makes the chemical theory depth profiling is not perfect and make students deviation in understanding [1].

Insufficient employment ability is one of the important reasons. College students' employment difficult employment capability and the colleges and universities to provide a higher education is closely related to the quantity and quality of service in colleges and universities should establish employment ability oriented new system of higher education. Employment ability oriented education system in colleges and universities refers to according to the need of society and the employment of college student ability to adjust the system of college education and its specification, in order to improve the education effect and the efficiency of human capital investment. Employment ability is an important angle of view, discusses college students' employment difficult reason and the size of the employment ability and is closely related to the quantity and quality of the education service in colleges and universities, improve the employment ability is an important approach to ease college students employment difficult. The school is not only a place for learning, and the place where college students to realize socialization [2]. We must have the higher level of social characteristics and university's mission is to help students develop a higher level of social characteristics.

In this paper, we conduct research on the integration of students' ability to explore and chemistry teaching method innovation from the ability oriented perspective. Colleges and universities should establish employment ability oriented new system of higher education, namely, according to the need of society and the employment of college student ability to adjust the system of college education and its specification, in order to improve the efficiency of human capital investment. The reform by teaching contents, teaching methods and education management three aspects to implement, and teaching management is the foundation of all teaching activities. In the next sub-sections, we will conduct in-depth research on the mentioned issues and challenges.

\section{The Proposed Methodology and Novel Perspective}

The Chemistry Teaching Methodologies. The purpose of university education is to cultivate the students' ability, namely, cultivate students' innovative consciousness, innovative thinking and creativity. Innovation should be the university educational philosophy, also is the soul of a university. College teachers should not only teach students new knowledge, to cultivate the student to obtain more knowledge, use knowledge and problem solving skills, namely, innovation and creativity. In daily chemistry teaching in colleges and universities should pay attention to the students to build a harmonious and equal teaching atmosphere, in the teaching environment is easy to reduce the distance between teachers and students feelings, it is good for students to find problems, ask questions, and are willing to solve the problem, so their innovation consciousness naturally got the training and play. At the same time in the teaching, pay attention to the use of lively, interesting science methods to cultivate the students' interest in learning, and encourage students to bold imagination, fantasy, let the fantasies with innovation, cultivate the students' innovation consciousness.

Teachers should actively guide in experiment teaching, make students from inner experience to their hands-on practice and bring joy, surprise and satisfaction. Consciously bring experiments, 
intuitive interest lead to chemical change of causality or nature of the experiment research. Purposefully to inspire and cultivate students' awareness of lasting interest, make it become not only completes the power of the chemical experiment, has become the important factor to promote the development of students' psychological quality. Chemistry experiment at the center of the task is to cultivate the students' scientific quality and experimental work ability, in the experiment teaching should not only attach importance to the cultivation of the student operation skills and also must pay attention to develop students' scientific thinking method. Chemistry teaching method reform, by doing a lot with close links to the quality-oriented education of the public welfare social practice activities, consolidate knowledge, improve the students' cultural quality, further enrich the extracurricular study life. Reform the traditional teaching method, to improve teacher centered, centering on the textbook traditional lecture teaching methods, enhance the students' autonomous learning consciousness, in the process of participation in social practice ability to raise awareness of the essence of things, cultivate autonomous learning ability which will make the students realize the scientific development and the practical significance and value of life. Learn chemical knowledge is related to their future work, life and future, let students understand chemistry course of study at the same time, not to learn book knowledge, which will do the test is successfully completed the courses of study and must in the ideological understanding and soul really understand and truly realized the importance of quality education which will hold special meaning and importance [3-4].

\section{The Ability Oriented Perspective.} Innovation ability is a college student should have the comprehensive ability of the most important thing in a kind of ability. College teachers in the teaching work to continuously optimize the teaching content, hold innovation education the key to further deepen the teaching reform. Using heuristic teaching method and modern teaching means to stimulate students' interest in learning, guide students to actively participate in teaching activities, respect students' individual character development and consciously cultivate them. Establish employment ability oriented education system in colleges and universities which should follow the following three basic principles. Effectiveness. The essence of higher education is to pass knowledge and skills to students, and let students accept and absorb. Improve the teaching quality of college education, is to raise the proportion of college students' actual to accept and absorb the knowledge and skills. The practicability of content and the unit of choose and employ persons are willing to hire a university student, depending on the college students can be competent for a job the unit. Depends on whether he can create more value for the unit. Colleges and universities should be based on more realistic need to adjust the education content and its changes, in order to improve the students' employment ability and practical ability to work. Teaching method is to pass on the knowledge and skills to the specific way of students, can affect the teaching effect. Education in colleges and universities should pay attention to their aptitude, college students' learning initiative into full play. (2) Flexibility. Colleges and universities to provide education services to reflect the social demand and the diversification of college students' preference and has certain flexibility, emphasize the power of the students, in order to improve the actual effect of college students' learning. Provide greater selectivity. It is the ability to adapt to the college students a variety of mental and spiritual needs. Colleges and universities to open enough classes and lectures, and give students a larger choice space, in order to reflect the flexibility and higher education of college students' learning. (3) The comprehensive. Colleges and universities to enhance college students' comprehensive quality, 
promote the all-round development of college students, compound talents. This is the foundation of university student, as well as college students, are the basic premise of implementation. Colleges and universities should teach the students how to people skills, and help to form the correct outlook on life, positive attitude, the spirit of hard learning, good professional morality, learn to cut bait, tolerance and Thanksgiving, learn to communicate with the team cooperation, and have a collective sense of honor and patriotic enthusiasm. In the figure one, we illustrate the general perspective of the ability oriented teaching.

\begin{tabular}{|c|c|c|}
\hline $\begin{array}{l}\text { - What a colloid is; what Rayleigh } \\
\text { scattering is; what optical density } \\
\text { is } \\
\text { - How light is scattered from } \\
\text { particles } \\
\text { - That light scattering can, in some } \\
\text { circumstances, be used as an } \\
\text { indirect measure of particle size }\end{array}$ & $\begin{array}{l}\text { By reading the experiment notes } \\
\text { and references } \\
\text { By discussion with the laboratory } \\
\text { partner and the demonstrating } \\
\text { staff }\end{array}$ & \multirow{4}{*}{$\begin{array}{l}\text { - By discussion with demonstrating } \\
\text { staff } \\
\text { - By the quality of the written } \\
\text { report, including answers to the } \\
\text { questions asked in the experiment } \\
\text { - By exhibiting an understanding of } \\
\text { the strengths and weaknesses of } \\
\text { the methods } \\
\text { - By the differences noted between } \\
\text { the two measurement techniques } \\
\text { - By feedback with the experiment } \\
\text { marker in the oral examination }\end{array}$} \\
\hline $\begin{array}{l}\text { That a commonly used piece of } \\
\text { experimental apparatus } \\
\text { (UV-vis spectrometer) can be } \\
\text { used for a purpose outside its } \\
\text { initially envisaged scope }\end{array}$ & $\begin{array}{l}\text { - By performing the experiment } \\
\text { and determining the size of } \\
\text { various sample particles. }\end{array}$ & \\
\hline $\begin{array}{l}\text { - What Transmission Electron } \\
\text { Microscopy (TEM) is and what } \\
\text { type of particle may be } \\
\text { successfully imaged by TEM }\end{array}$ & $\begin{array}{l}\text { - By understanding the principles of } \\
\text { TEM and by obtaining TEM } \\
\text { images of their latex suspensions }\end{array}$ & \\
\hline $\begin{array}{l}\text { - The difference between direct and } \\
\text { indirect (weighted) measurements } \\
\text { of a quantity }\end{array}$ & $\begin{array}{l}\text { - By understanding why the two } \\
\text { methods (light scattering and TEM) } \\
\text { give different answers for particle } \\
\text { diameter }\end{array}$ & \\
\hline
\end{tabular}

Figure 1. The General Perspective of the Ability Oriented Teaching for Chenistry Education

\section{The Integration of Students' Ability and} Chemistry Teaching Method. In chemistry teaching practice, teachers should carefully study the teaching material, combining the actual situation of students, innovative design, unique teaching program do import interesting classroom teaching goals, choose to stimulate student interest in exploring teaching strategies, expand students' thinking and plans to do relaxation. Chemistry teaching courseware design should be integrated into the relevant subject knowledge, in the teaching, teachers use various teaching in the spirit of innovation design, fully building a harmonious teaching environment, further optimize chemical teaching effect, its methods varied, teaching design should make full use of the advantages of modern information technology. Teachers according to the teaching material content design novel and unique teaching scheme and teaching courseware, to the attention of students within a tightly controlled in chemistry classroom, and boost the enthusiasm of the students to explore new knowledge.

Teachers in the design of teaching plan, make full use of modern multimedia technology, the content of teaching materials and teaching point to elaborate design and innovation, greatly attracted the attention of students, enhance the learning interest and desire to explore and improve the efficiency of classroom teaching. In the process of chemistry teaching courseware design, teachers should use chemistry curriculum innovation education in classroom teaching practice, the chemistry discipline itself has scientific value and life closely with practice, enhance the learning interest and strengthen the implementation of quality education. The need of 
the current education reform, the development of information technology innovation closely contact with chemical experiment teaching, in the process of innovative teaching, for students active learning and effective way to provide the best teaching environment, so as to realize organic combination of textbook knowledge learning and the students' real life of the good effect. The reality of teachers from the students, strengthen the learning interest cultivation, combined with interesting knowledge in chemistry teaching material, through the reform of traditional teaching methods, the construction of a harmonious class teaching situation. To build a harmonious classroom teaching situation, it needs teachers from reform the traditional teaching mode, need to mobilize students' learning enthusiasm and develop knowledge to explore the interest of scientific knowledge and learning guidance.

\section{Conclusion}

In this paper, we conduct research on the integration of students' ability to explore and chemistry teaching method innovation from the ability oriented perspective. In the teaching, teachers should change the traditional teaching method, in addition to teach students to master the basic knowledge and understanding of chemistry at the same time, to guide students to focus on society, concerned about the environment. Teachers should be timely the concept of green chemistry through teaching process, let the students under the influence of the concept of green chemistry. Gradually learn from the viewpoint of green ideas to study, research and application of chemical and become a kind of guiding ideology of their study and work in the future. The proposed methodology and approach takes the advantages of the novel perspective which will be meaningful and necessary.

\section{References}

[1] Feng Q, Chang B, Bing H E, et al. Study on Application of Virtual Experiment in Physical Chemistry Teaching[J]. Journal of Chengdu Normal University, 2014.

[2] Chen L, Chemistry D O, Science C O, et al. Discussion on Chemistry Teaching Reform for Agricultural College Undergraduate Education[J]. Journal of Anhui Agricultural Sciences, 2014.

[3] Wang, X. L., Bao, X., Li, L. I., \& Chen, Y. H. (2014). Discussion about penetration of green chemistry in university chemistry teaching. Guangzhou Chemical Industry.

[4] Guo L. Discussion on Application of the Project Teaching Method in Physical Chemistry Teaching[J]. Guangdong Chemical Industry, 2014. 